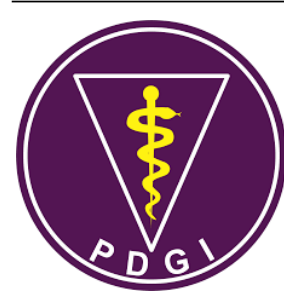

\title{
The Effect of Presto Cooker as an Alternative Sterilizer Device for Dental Equipment
}

\author{
Ariadna Adisattya Djais ${ }^{1 \S}$, Citra Fragrantia Theodorea ${ }^{1}$ \\ ${ }^{1}$ Department of Oral Biology, Faculty of Dentistry, University of Indonesia, Indonesia
}

Received date: February 3, 2019. Accepted date: March 21, 2019. Published date: April 30, 2019

\author{
KEYWORDS \\ Candida albicans; \\ Porphyromonas gingivalis; \\ presto; \\ Staphylococcus aureus; \\ sterilizer; \\ Streptococcus mutans
}

\begin{abstract}
Introduction: In the suburb area of Indonesia, autoclaves as a sterilizer could not been used optimally due to inadequate electrical capacity. An alternative sterilizer such as a pressure cooker (presto) have been choosen because it has same principle as an autoclave, but it doesn't required the electrical supply. Nevertheless, the procedure of presto in dentistry remain unclear. Objective: To obtain a standard procedure by using presto cooker for dental instrument sterilization. Methods: The effect of presto was observed on aerobic ( $S$. aureus ATCC $25923^{\mathrm{T}}$ ), facultative anaerobes $\left(S\right.$. mutans ATCC $\left.25175^{\mathrm{T}}\right)$, anaerobes $(P$. gingivalis ATCC $\left.33277^{\mathrm{T}}\right)$ and yeasts $\left(\right.$ C. albicans ATCC $\left.10231^{\mathrm{T}}\right)$ which are exposed to the dental mirror. Each dental mirror (triplo) was dipped for 3 minutes on media containing bacteria $\left(10^{6}\right.$ bacteria/ $\mathrm{mL}$ ). Furthermore, the dental mirrors were cooked at presto (MAXIM, 7 L, Indonesia) which contained $500 \mathrm{~mL}$ of water, for 15,30 and 45 minutes. Bacterial growth analysis were observed visually and microscopically after Gram staining. Results: In the $S$. aureus ATCC $25923^{\mathrm{T}}$ and $C$. albicans ATCC $10231^{\mathrm{T}}$ groups, up to 30 minutes the color of the media showed cloudy but remained clear when sterilized for 45 minutes. Likewise, these groups showed appereance of bacterial growth for 15-30 minutes but didn't appear to grow in 45 minutes. While in the $S$. mutans ATCC $25175^{\mathrm{T}}$ and $P$. gingivalis ATCC $33277^{\mathrm{T}}$ groups, up to 15 minutes the color of the media showed cloudy but remained clear after being sterilized for 30 minutes. In addition, these groups showed appereance of bacterial growth for 15 minutes but absence in 30-45 minutes. Conclusion: Presto can be used as one of alternative equipment to sterilize dental instrument, effectively. The optimal killing time of bacteria and yeast was 45 minutes.
\end{abstract}

\footnotetext{
$\S$ Corresponding Author

E-mail address: ariedjais26@gmail.com (Djais AA)
}

\section{DOI: https://doi.org/10.32793/jida.v2i1.356}

Copyright: (02019 Djais AA, Theodorea CF. This is an open access article distributed under the terms of the Creative Commons Attribution License, which permits unrestricted use, distribution, and reproduction in any medium provided the original author and sources are credited. 


\section{KATA KUNCI}

Candida albicans; Porphyromonas gingivalis; presto cooker; Staphylococcus aureus; sterilisasi;

Streptococcus mutans

\section{PENDAHULUAN}

Metode alat sterilisasi yang umumnya digunakan dalam bidang kedokteran adalah panas lembab (tekanan uap dalam autoklaf), panas kering (oven udara panas), dan bahan kimia gas (chemiclave). Metode sterilisasi lainnya yang tidak digunakan dalam kedokteran gigi adalah gas etilen oksida, iradiasi gamma dan penyaringan. ${ }^{1,2}$ Tekanan uap merupakan tindakan sterilisasi yang sangat efektif karena dapat membebaskan atau merubah panas uap sehingga membentuk air. Kondisi ini berpotensi membunuh mikroorganisme, sedangkan volume uap yang berkontraksi dapat memperkuat penetrasi. ${ }^{2}$ Fenomena yang digunakan pada sterilisasi uap oleh autoklaf, yaitu ketika air dipanaskan pada lingkungan yang tertutup, naiknya titik didih berhubungan dengan suhu uap yang dihasilkan. Misal; pada $104 \mathrm{kPa}$ (15 psi) suhu uap yang dihasilkan adalah $121^{\circ} \mathrm{C}^{2,3}$ (Tabel 1).
Alat sterilisasi yang menjadi standar pada bidang kedokteran gigi adalah autoklaf. Alat sterilisasi ini merupakan alat pemanas tertutup yang digunakan untuk mensterilkan suatu benda dengan menggunakan uap pada suhu dan tekanan tinggi $\left(121^{\circ} \mathrm{C}, 15 \mathrm{lbs}\right)$ selama kurang lebih 15 menit. ${ }^{4,5}$ Autoklaf ditujukan untuk membunuh endospora, karena sel ini dapat dibunuh pada suhu $100^{\circ} \mathrm{C}$ yang merupakan titik didih air pada tekanan atmosfer normal. Pada suhu $121^{\circ} \mathrm{C}$, endospora dapat dibunuh dalam waktu 4-5 menit, sedangkan vegetative bakteri dapat dibunuh hanya dalam waktu 6-30 detik pada suhu $65^{\circ} \mathrm{C}{ }^{4}$. Adapun komponen-komponen yang terdapat pada autoklaf, adalah: bejana tekan, ruang air, ruang uap, elemen panas (yang dapat mendidihkan air sehingga menjadi uap), katup uap (untuk membuang udara terjebak), katup pengaman (untuk membuang uap berlebih), sensor suhu (termometer) dan pressure Gauge (untuk mengetahui tekanan dalam autoklaf). ${ }^{4}$

Tabel 1. Daftar tekanan, temperatur dan waktu untuk sterilisasi

\begin{tabular}{ccccc}
\hline $\begin{array}{c}\text { Temperatur } \\
\left({ }^{\circ} \mathrm{C}\right)\end{array}$ & \multicolumn{2}{c}{ Tekanan } & $\begin{array}{c}\text { Waktu tunggu } \\
(\text { menit })\end{array}$ & $\begin{array}{c}\text { Waktu siklus } \\
\text { keseluruhan } \\
\text { (menit) }\end{array}$ \\
\cline { 2 - 4 } $134-138$ & $\mathrm{psi}$ & $\mathrm{kPa}$ & 3 & 20 \\
$126-129$ & 20 & 207 & 10 & 30 \\
$121-124$ & 15 & 138 & 15 & 40 \\
$115-118$ & 10 & 69 & 30 & 50 \\
\hline
\end{tabular}


Pressure cooker (presto) merupakan alat masak yang umumnya digunakan untuk melunakkan tulang, melunakkan ikan, daging dan sebagainya. Prinsip kerja dari alat masak ini sama dengan prinsip kerja autoklaf. Komponen yang terdapat pada autoklaf, dapat ditemukan juga pada presto, seperti: bejana tekan, ruang air, ruang uap, elemen panas dan katup pengaman. ${ }^{6}$ Pada alat masak ini tidak terdapat katup uap yang berfungsi untuk membuang udara yang terjebak, selain itu pada alat ini tidak ada komponen termometer dan pressure Gauge, sehingga informasi tentang suhu $121^{\circ} \mathrm{C}$ dan tekanan 15 lbs, hanya diestimasikan dengan naiknya bandul pengaman dan keluarnya asap melalui katup tersebut, sehingga mengisyaratkan bahwa suhu telah mencapai lebih dari $100^{\circ} \mathrm{C}$, dan tekanan yang dicapai adalah lebih tinggi dari 1 atmosfer. ${ }^{7}$ Berikut spesifikasi presto (MAXIM) yang digunakan sebagai alat uji, antara lain: volume air $500 \mathrm{~mL}$, waktu 30 menit sejak katup pertama kali mengeluarkan uap, dan tekanan dalam presto 80 KPA. Upaya untuk mendapatkan hasil akhir yang sama dengan metode kerja autoklaf yaitu kondisi alat yang steril, walau tanpa indikator termometer dan pressure Gauge adalah dengan melakukan perpanjangan waktu setelah melebihi titik didih air, dimana indikator katup atau bandul pengaman terangkat yang ditandai ketika presto mengeluarkan bunyi.

Walaupun alat standar autoklaf umumnya tersedia di Puskesmas atau tempat pelayanan kesehatan masyarakat lainnya, namun alat tersebut belum dapat digunakan secara optimal. Hal ini terutama disebabkan oleh karena faktor penunjang seperti kapasitas listrik ditempat tersebut yang kurang memadai. Sehingga diupayakan suatu alat yang berhasil guna dengan indikator harga relatif murah serta tidak membutuhkan faktor penunjang seperti beban kapasitas listrik yang cukup tinggi. Berkaitan dengan hal tersebut maka dipilih alat masak presto yang mempunyai komponen-komponen mirip dengan autoklaf dan sebagai sumber energi panas yang dapat digunakan kompor tanpa listrik. Kekurangan presto dibandingkan autoklaf berkaitan dengan hal di atas adalah alat ini tidak memiliki ukuran temperatur dan ukuran tekanansehingga besarnya tekanan pada alat presto bersifat pasif tergantung dari beratnya bandul. Adapun indikator yang digunakan untuk melihat keberhasilan sterilisasi pada penelitian ini dilakukan uji laboratorium dari alat yang disterilkan yaitu dengan variabel waktu. Berdasarkan data tersebut, maka dibuatkan panduan untuk aplikasi klinik.

Pada penelitian ini, alat standar kedokteran gigi yang diuji adalah kaca mulut. Pemilihan kaca mulut sebagai alat uji disebabkan alat ini diasumsikan paling sulit untuk disterilkan dibandingkan dengan alat-alat kedokteran gigi lainnya seperti pinset, gunting, dan sebagainya. Kaca mulut terdiri dari dua bagian yaitu cermin bulat dan kerangka logam yang berfungsi untuk mengikat kaca tersebut. Walau oleh pabrik telah diupayakan tidak berjarak antara kerangka dan cermin, namun diantara kedua komponen tersebut tetap terdapat celah dalam ukuran mikrometer. Celah tersebut sangat sulit dijangkau/dibersihkan bila terpapar oleh mikroorganisme.

Staphylococcus aureus merupakan bakteri yang sering ditemukan pada kavitas oral. S. aureus memiliki proporsi isolasi yang tinggi pada saliva dari orang tua sehat yang berumur lebih dari 70 tahun. Habitat dari $S$. aureus adalah kulit, yang umumnya dapat bertransmisi melalui tangan. Selain itu, bakteri ini dapat tercemar melalui udara dan debu, serta sering kali ditemukan di lingkungan rumah sakit. Karakteristik $S$. aureus adalah kokus berkelompok positif Gram, tidak berspora, nonmotile, berkapsul pada beberapa strain, tumbuh secara aerob dengan koloni berwarna kuning atau emas pada media agar darah, positif-katalase. ${ }^{8,9}$

Streptococcus mutans adalah bakteri fakultatif anaerob. Bakteri ini merupakan bagian dari streptokokus oral yang memiliki proporsi terbesar diseluruh bakteri oral. Pada kultur, bakteri ini kokus berantai positif Gram, $\alpha$-hemolisis, katalase negatif. Berbeda dengan pneumokokus, streptokokus oral pada pertumbuhannya tidak terhambat oleh bile atau optochin (ethylhydrocupreine hydrochloride). Kelompok S. mutans merupakan agen utama pada karies gigi. Karakteristik mereka adalah kemampuannya menghasilkan polisakarida ekstraseluler yang lengket dalam jumlah yang besar. Apabila terdapat karbohidrat di lingkungannya, maka kondisi ini berpotensi membantu bakteri menempel ke enamel atau berikatan antar mereka. Pada manusia hanya dikenal tiga serotype S. mutans yakni serotype c, e dan f. ${ }^{10,11}$

Porphyromonas gingivalis adalah bakteri anaerob obligat yang memiliki karakter, bakteri batang pleomorfik negatif Gram, non-motil, asaharolitik. $P$. gingivalis, dapat tumbuh dalam suasana strik anaerob dan membutuhkan hemin dan vitamin K. Pada lokasi intra oral, bakteri ini ditemukan dalam jumlah kecil di sulkus gingiva dan biofilm subgingival. Bakteri ini berkaitan dengan periodontitis kronis dan abses dentoalveolar. $P$. gingivalis memproduksi enzim protease, a haemolisin, kolagenase, yakni enzim yang mendegradasi kolagen, dan hasil metabolit yang bersifat sitotoksik. ${ }^{12}$

Candida albicans adalah yeast dari golongan Deuteromycota, spesies ini merupakan penyebab infeksi oportunistik yang disebut kandidiasis pada kulit mukosa dan organ dalam manusia. Karakteristik spesies ini adalah berbentuk seperti telur atau sferis dengan diameter 3-5 $\mu \mathrm{m}$ dan dapat memproduksi pseudohifa. Spesies ini merupakan penyebab infeksi oportunistik yang disebut kandidiasis pada kulit mukosa dan organ dalam manusia. 
Karakteristik spesies ini adalah berbentuk seperti telur atau sferis dengan diameter 3-5 $\mu \mathrm{m}$ dan dapat memproduksi pseudohifa. Spesies ini mempunyai dua jenis morfologis, yaitu bentuk seperti khamir dan bentuk hifa. ${ }^{13,14}$

Penelitian ini bertujuan untuk mendapatkan suatu standar prosedur penggunaan presto secara rinci untuk mendapatkan hasil steril pada alat standar kedokteran gigi. Manfaat penelitian ini adalah (i) mengetahui waktu optimal yang dibutuhkan oleh presto untuk membunuh bakteri dan jamur, (ii) menginformasikan kepada tenaga kesehatan yang bertugas di lokasi pelayanan kesehatan yang mempunyai kendala keterbatasan kapasitas energi listrik, maka metode ini dapat digunakan sebagai tindakan alternatif pengganti autoklaf.

\section{BAHAN DAN METODE}

Jenis penelitian ini adalah eksperimen laboratorik in vitro yang dirancang untuk membuktikan efek panas dan tekanan uap dari presto yang dapat membunuh bakteri aerob, fakultatif anaerob, anaerob dan yeast ketika dipaparkan pada alat kesehatan, khususnya alat standar kedokteran gigi.

Pada penelitian ini yang digunakan sebagai alat standard kedokteran gigi adalah kaca mulut steril yang di uji secara triplo, masing-masing dicelupkan selama 3 menit pada media yang berisi kelompok bakteri yang telah diukur jumlahnya $\left(10^{6}\right.$ bakteri/mL). Kelompok 1 menggunakan bakteri uji: Staphylococcus aureus ATCC $25923^{\mathrm{T}}$, Kelompok 2: menggunakan bakteri uji Streptococcus mutans ATCC $25175^{\mathrm{T}}$, Kelompok 3: menggunakan bakteri uji Porphyromonas gingivalis ATCC $33277^{\mathrm{T}}$, dan Kelompok 4: menggunakan yeast uji Candida albicans ATCC 25923 $3^{\mathrm{T}}$. Kontrol negatif yang digunakan pada penelitian ini adalah kaca mulut steril tanpa kontaminasi bakteri. Sedangkan kontrol positif yang digunakan berupa media yang berisi bakteri yang tidak diberi perlakuan.

Kaca mulut yang telah dikontaminasi oleh masingmasing bakteri tersebut dimasukan ke sterile pouch (medic pack) dan kemudian dimasukan ke dalam presto (MAXIM, 7 L, Indonesia) yang telah diisi dengan air sebanyak $500 \mathrm{~mL}$. Presto dipanaskan di atas kompor, setelah bandul pengaman terangkat dan presto berbunyi, ditunggu selama 15 menit, baru kompor dimatikan dan diamkan presto hingga mencapai suhu ruang. Prosedur tersebut dilakukan untuk uji 30 menit dan 45 menit.

Setelah suhu presto mencapai suhu ruang, kaca mulut yang sebelumnya telah dipapar oleh bakteri $S$. mutans dan $P$. gingivalis diambil dan dimasukan dalam media Brain Heart Infusion (BHI) Broth, kemudian diinkubasi $37^{\circ} \mathrm{C}$ selama 48 jam dalam suasana anaerob dengan menggunakan sistim gaspack. Sedangkan untuk bakteri $S$. aureus diinkubasi $37^{\circ} \mathrm{C}$ selama 48 jam dalam suasana aerob. Pada kaca mulut yang sebelumnya dipapar dengan $C$. albicans diambil dan dimasukan ke dalam media cair Sabouroud kemudian di inkubasi $37^{\circ} \mathrm{C}$ selama 48 jam dalam suasana aerob.

Analisis terhadap pertumbuhan bakteri diamati dengan menggunakan dua cara, yaitu: (i) secara visual, ada/tidaknya pertumbuhan bakteri diamati dengan melihat perubahan warna pada media kultur cair ketika dimasukkan kaca mulut yang telah disterilisasi dengan menggunakan presto selama 15, 30 dan 45 menit. (ii) Secara mikroskopik, ada atau tidaknya pertumbuhan bakteri diamati dibawah mikroskop setelah dilakukan pewarnaan Gram.

\section{Alur Penelitian}

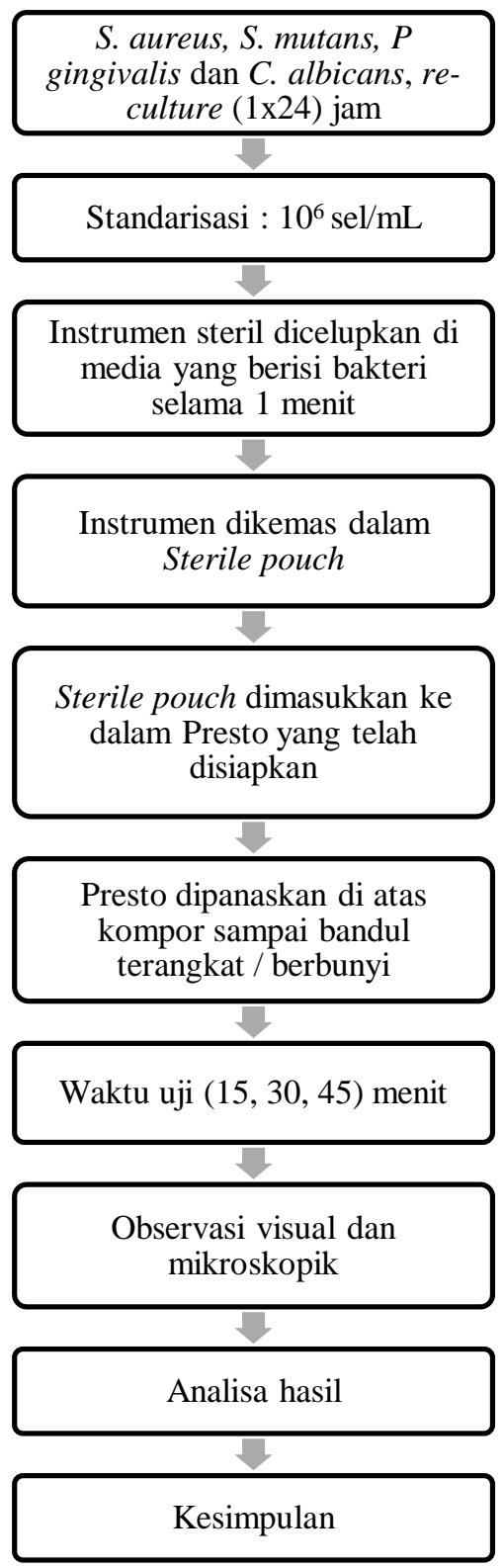


HASIL

Hasil inkubasi kaca mulut ke dalam masing media kultur cair menunjukkan ada atau tidaknya aktivitas pertumbuhan bakteri pada kaca mulut tersebut. Pengamatan pertumbuhan bakteri diamati secara visual terhadap perubahan warna media kultur cair (Tabel 2). Pada kelompok 1 dan 4, perubahan warna media kultur cair tampak keruh ketika dimasukkan kaca mulut yang telah disterilisasi dengan menggunakan presto selama 1530 menit. Kondisi media kultur cair tetap bening ketika kaca mulut disterilkan selama 45 menit. Sedangkan pada kelompok 2 dan 3, perubahan warna media kultur cair setelah kaca mulut disterilkan selama 15 menit menjadi keruh. Selain itu, tidak terjadi perubahan warna pada media kultur cair kelompok 2 dan 3 tersebut, selama 3045 menit.

Selain diamati secara visual, ada atau tidaknya aktivitas pertumbuhan bakteri pada kaca mulut dapat diamati secara mikroskopik setelah dilakukan pewarnaan Gram (Tabel 3). Pada kelompok 1 dan 4 menunjukkan adanya pertumbuhan bakteri yang dapat diamati secara mikroskopik pada kaca mulut yang telah disterilkan dengan menggunakan presto selama 15-30 menit. Pengamatan pertumbuhan bakteri dari kedua kelompok tersebut tidak ditemukan pada kaca mulut yang telah disterilkan selama 45 menit. Sedangkan pada kelompok 2 dan 3, pengamatan pertumbuhan bakteri ditemukan pada kaca mulut yang telah disterilkan dengan menggunakan presto selama 15 menit. Sedangkan pengamatan pertumbuhan bakteri secara mikroskopik tidak ditemukan pada kaca mulut yang telah disterilkan selama 30-45 menit.

\section{PEMBAHASAN}

Pada pemanasan selama 15 menit seluruh mikroorganisme uji tetap tumbuh, menunjukan pada saat itu kondisi panci presto menunjukan suhu kurang dari $121^{\circ} \mathrm{C}$ dengan tekanan 15 psi. Hal ini ditunjukan dengan media bakteri menjadi keruh yang memperlihatkan adanya pertumbuhan bakteri yang juga dikonfirmasi dengan pengamatan sel bakteri setelah dilakukan pewarnaan Gram. Pada menit ke-30, kedua mikroorganisme yang hidup dalam suasana aerob (S. aureus, C. albicans) masih dapat bertahan hidup, sedangkan bakteri fakultatif anaerob dan anaerob dapat dibunuh. Pada menit ke-45, seluruh mikroorganisme yang diuji sudah terbunuh dengan indikator media bakteri tetap jernih dan hasil pengamatan dibawah mikroskop setelah dilakukan pewarnaan Gram tidak tampak adanya bakteri.

Tabel 2. Hasil pengamatan pada perubahan warna kultur setelah kaca mulut disterilkan dengan menggunakan presto selama 15,30 dan 45 menit

\begin{tabular}{|c|c|c|c|c|c|c|c|c|c|c|}
\hline \multicolumn{2}{|c|}{ Bakteri } & \multicolumn{3}{|c|}{$\begin{array}{c}15 \text { menit } \\
\text { Visual }\end{array}$} & \multicolumn{3}{|c|}{$\begin{array}{c}30 \text { menit } \\
\text { Visual }\end{array}$} & \multicolumn{3}{|c|}{$\begin{array}{c}45 \text { menit } \\
\text { Visual }\end{array}$} \\
\hline S. aureus & ATCC $25923^{\mathrm{T}}$ & K & $\mathrm{K}$ & K & K & $\mathrm{K}$ & K & $\mathrm{B}$ & B & B \\
\hline S. mutans & ATCC $25175^{\mathrm{T}}$ & K & $\mathrm{K}$ & $\mathrm{K}$ & B & $\mathrm{B}$ & $\mathrm{B}$ & $\mathrm{B}$ & B & B \\
\hline P. gingivalis & ATCC $33277^{\mathrm{T}}$ & K & $\mathrm{K}$ & $\mathrm{K}$ & B & $\mathrm{B}$ & $\mathrm{B}$ & $\mathrm{B}$ & B & B \\
\hline C. albicans & ATCC $25923^{\mathrm{T}}$ & K & $\mathrm{K}$ & $\mathrm{K}$ & K & $\mathrm{K}$ & K & $\mathrm{B}$ & B & B \\
\hline
\end{tabular}

$\mathrm{B}=$ Bening; $\mathrm{K}=$ Keruh

Tabel 3. Hasil pengamatan ada atau tidaknya pertumbuhan bakteri secara mikrokopik setelah kaca mulut disterilkan dengan menggunakan presto selama 15, 30 dan 45 menit

\begin{tabular}{|c|c|c|c|c|c|c|c|c|c|c|}
\hline \multicolumn{2}{|c|}{ Bakteri } & \multicolumn{3}{|c|}{$\begin{array}{c}15 \text { menit } \\
\text { Visual }\end{array}$} & \multicolumn{3}{|c|}{$\begin{array}{c}30 \text { menit } \\
\text { Visual }\end{array}$} & \multicolumn{3}{|c|}{$\begin{array}{c}45 \text { menit } \\
\text { Visual }\end{array}$} \\
\hline S. aureus & ATCC $25923^{\mathrm{T}}$ & + & + & + & + & + & + & - & - & - \\
\hline S. mutans & ATCC $25175^{\mathrm{T}}$ & + & + & + & - & - & - & - & - & - \\
\hline P. gingivalis & ATCC $33277^{\mathrm{T}}$ & + & + & + & - & - & - & 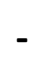 & - & - \\
\hline C. albicans & ATCC $25923^{\mathrm{T}}$ & + & + & + & + & + & + & - & - & - \\
\hline
\end{tabular}

$(+)=$ tampak bakteri dibawah mikroskop, $(-)=$ Tidak tampak bakteri dibawah mikroskop 
Pemilihan bakteri S. aureus oleh karena bakteri ini berkaitan dengan pembentukan pus pada kasus infeksi, serta merupakan bakteri uji untuk mendeteksi Methicilin Resistant $S$. aureus (MRSA). ${ }^{15}$ S. mutans merupakan etiologi utama bakteri penyebab karies gigi, ${ }^{10}$ oleh karenanya dipilih sebagai salah satu bakteri uji pada penelitian ini. Adapun pemilihan bakteri $P$. gingivalis, dipilih oleh karena bakteri ini merupakan bakteri yang berperan besar pada infeksi jaringan periodontal. ${ }^{16} C$. albicans adalah satu-satunya jamur yang berperan besar pada penyakit mulut seperti karies gigi serta penyakit jaringan periodontal. ${ }^{17}$

\section{KESIMPULAN}

Presto dapat digunakan sebagai alat alternatif untuk mensterilkan alat standar kedokteran gigi secara efektif dan efisien. Waktu optimal untuk membunuh bakteri dan yeast menggunakan presto adalah 45 menit yang didiamkan setelah katup pengaman mengeluarkan uap atau berbunyi. Setelah 45 menit, kompor baru dimatikan sumber panasnya. Prosedur yang dianjurkan pada alatalat kedokteran gigi sebelum disterilkan menggunakan presto adalah alat standar tersebut harus dicuci dahulu dengan sikat gigi dan air sabun untuk mereduksi kotoran dan jumlah bakteri yang terdapat pada alat tersebut selanjutnya dibilas dengan air bersih kemudian dimasukan ke dalam sterile pouch. Panci presto diisi dengan air sebanyak $500 \mathrm{~mL}$, setelah itu sterile pouch yang berisi alat standar kedokteran gigi dimasukan dalam presto kemudian ditutup dengan rapat. Sumber panas diaktifkan, setelah bandul terangkat dan presto akan mengeluarkan bunyi, ditunggu hingga 45 menit, kemudian sumber panas dimatikan. Presto dibuka setelah suhu mencapai sekitar $30^{\circ} \mathrm{C}$.

\section{UCAPAN TERIMA KASIH}

Penulis mengucapkan terima kasih kepada Pak Djaja Suhardja atas kontribusinya di laboratorium Biologi Oral, FKG UI. Penelitian ini didukung oleh Hibah P2M UI tahun 2018.

\section{KONFLIK KEPENTINGAN}

Penulis menyatakan tidak terdapat konflik kepentingan yang berkaitan dengan manuskrip ini.

\section{DAFTAR PUSTAKA}

1. Bargale S, Patel N, Dave B, Poonacha KS, Ardeshana A, Mehta D. Assessment of sterilization technique practices at dental clinics of Vadodara, Gujarat India. Sch J Dent Sci. 2016;3(9):240-246.

2. Alder VG, Brown AM, Gillespie WA. Disinfection of heat-sensitive material by low-temperature steam and formaldehyde. J Clin Pathol. 1966;19(1):83-89.

3. N Vishal Gupta, Shukshith KS. Qualification of autoclave. Int J Pharm Tech Res. 2016; 9(4):220226.

4. Madigan MT, Martinko JM, Brock TD. Brock Biology of Microorganisms. New Jersey: Pearson Prentice Hall; 2006.

5. Baird RM, Hodges NA, Denyer SP. 2000. Handbook of microbiological quality control: pharmaceutical science. USA: CRC Press; 2000.

6. DD Date, Tated RG. Pressure cooker lid-literature review. International Journal of Advance Research Ideas and Innovations in Technology (IJARIIT). 2018;4(3):2388-96.

7. Everall PH, Morris CA, Yarnell R. Sterilization in the laboratory autoclave using direct air displacement by steam. J Clin Pathol. 1978;31(2):144-147.

8. Marin LFC, Arciniegas GE, and Vivas MC. Characterization of Staphylococcus aureus isolates that colonize medical students in a hospital on the city of Cali, Columbia. Int $\mathrm{J}$ Microbiol. 2015;2015:10358489.

9. Abulkasim HM, GS Shukla, HK Bajaj and Masih H. Antimicrobial resistance of Staphylococcus aureus among healthy and adult students. Int J Pharm Sci Res. 2017; 8(12):5247-5251.

10. Cheon K, Moser SA, Wienner HW, Whiddon J, Momeni SS, Ruby JD, et al. Characteristics of Streptococcus mutans genotypes and dental caries in children. Eur J Oral Sci. 2013; 121(301):148-155.

11. Mounika S, Jagannathan N, Murali. Association of Streptococcus mutans and Streptococcus sanguis in act of dental caries. J Pharm Sci Res. 2015;7(9):764766.

12. How KY, Song KP, Chan KG. Phorphyromonas gingivalis: an overview of periodontopathic pathogen below the gum line. Front Microbiol. 2016;7:53.

13. Lof M, Janus MM, Krom BP. Metabolic interaction between bacteria and fungi in comensal oral biofilms. J Fungi. 2017;3(3):40.

14. Ghasempour M, Sefidgar SA, Eyzadian H, Gharakhani S. Prevalence of Candida albicans in dental plague and caries lesion of early childhood caries (ECC) according to sampling site. Caspian J Intern Med. 2011;2(4):304-308.

15. Adhikari R, Pant ND, Neupane S, Neupane N, Bhattarai R, Bhattas, et al. Detection of methicilin resistant Staphylococcus aureus and determination of minimum inhibitory concentration of vancomycin for Staphylococcus aureus isolated from pus /wound swab samples of patients attending a tertiary care hospital in Kathmandu Nepal. Can J Infect Dis Med Microbiol. 2017;2017(2191532):1-6. 
16. Rafiei M, Kiani F, Sayehmiri F, Sayehmiri K, Sheiki A, Azodi MZ. Study of Phorphyromonas gingivalis in periodontal disease: a systematic review and metaanalysis. Med J Islam Repub Iran. 2017;31: 62.
17. How KY, Song KP, and Chan KG. Porphyromonas gingivalis: An overview of periodontopathic pathogen below the gum line. Front Microbiol. 2016; 7: 53 . 